\begin{tabular}{|l||c|c||}
\hline \hline Received 17.11.2021 & JOTS \\
\hline \hline Accepted 02.12.2021 & Research Article & $6 / 1$ \\
\hline \hline Published 01.01.2022 & & $2022: 39-53$ \\
\hline
\end{tabular}

\title{
Dede Korkut'taki Demir Gücü Üzerine Bir Değerlendirme
}

\section{An Evaluation on Dämir Gücü in Dädä Qorqut}

\author{
Dursun Can EYÜBOĞLU* \\ (İstanbul/ Turkey) \\ E-mail:dursuncaneyuboglu@gmail.com
}

\begin{abstract}
Epics are related to both history and literature. Turks have a rich epic tradition. Dädä Qorqut epics have an important place in Turkic culture. They have important information about Turkic history, geography, language, literature, culture and art. Many personal name occurred in Dädä Qorqut narratives. One of them is Qaracuq Čoban's brother named Dämir Gücü. His name is mentioned in a story in the Book of Dädä Qorqut. Qaracuq Čoban has a strong and brave personality. Q1yan Gücü and Dämir Gücü have stood by their brothers and fought heroically against the enemy army. There is an exemplary devotion between Qaracuq Čoban and his brothers. In this article, the name and family of Dämir Gücü is examined.
\end{abstract}

Key Words: Dädä Qorqut, Salur Qazan, Qaracuq Čoban, Dämir Gücüu, Qıyan Gücü.

\footnotetext{
ORCID ID: 0000-0003-4163-0976.
} 


\section{J(ब)}

\section{Giriş}

Türk halk edebiyatı içerisinde önemli bir yere sahip olan destanın birçok tanımı yapılmıştır. Bunlardan biri şöyledir:

"Kahramanlı destanları harb, zafer, esaret, ölüm ve şenlik, şölen gibi duygu ve heyecanı kamçlayan olaylar sirasında herhangi bir ozan veya ozanlar tarafindan söylenen, kuvvetli olduğu nisbette yayllan ve az çok değişerek yaşayan milli mahsullerdir" (Tural, 2006: 54).

Türk destanları içerisinde önemli bir yere sahip olan Dede Korkut'un önemi konusunda çok şey söylenmiştir. Korkut adlı eserimizde bunların önemli bir kısmına yer vermiştik (Eyüboğlu, 2019: 16-28).

Dede Korkut'un önemini ortaya koyan sözlerden birkaçı şöyledir:

Ali Şir Nevâî:

(Korkut Ata) "Türk ulusu arasında şöhreti öyle fazladır ki başka şöhrete ihtiyacı yoktur. Kendisinden yll larca öncekini ve (yine) kendisinden yıllarca sonraki geleceği haber vermiştir. Çok öğüdü içine alan özlü sözleri ortadadır" (Akt. Kocasavaş, 2014: 143).

Fuat Köprülü:

“Bütün Türk edebiyatın terazinin bir gözüne, Dede Korkut’u öbür gözüne koysanı,, yine Dede Korkut ağır basar" (Akt. Ergin, 2017: 7).

Akselev Seydimbek:

“... Korkut karakteri, bilgeliğin ve kahramanliğın sembolü ve onun küyleri de zalimlik ve düşmanliğı yenen güzelliğin silinmez örneği olarak, nesillerin gönlünde ebediyen yaşayacaktır" (2000: 60).

Anar Rizayev:

"Azerbaycan türk xalqının şah eseri, Ana kitabı "Dede Qorqud" dastanıdır" (KitabiDede Korkud Ensilopediyası, 2000: 16).

Fuzuli Bayat:

"Mitolojik, tarihi, epik ve daha nice katmanlaşma yaşayan Korkut Ata, Türk dünyasında ününe, işlevlerine göre hiç kimseyle mukayese edilemeyecek birisidir. Denizlerden denizlere büyük devletler kuran konar-göçer Türklerin kahramanlık çağlarını zihnimizde yaşatan ve bizlere ulaştıran Korkut Ata, bütün Türk dünyasında her şeyi bilen bilgelik sembolüdür. Ayrıca Korkut Ata, bütün Türkleri birbirine bağlayan kişiliğe sahiptir. Her ne kadar tarihi veya efsanevi, şaman veya evliya gibi şekillerde karşımıza çıksa da Korkut, Türk milletinin gözünde Ata'dır. Bizi öz kimliğimize döndüren, bu günümüzle geçmişimizi 
bağlayan; tarihi, destana; deyimi ise atasözüne çeviren Korkut Ata, savaşçı olduğu kadar barışçı, alp olduğu kadar ozan, kutsal olduğu kadar da zekidir” (2016: 78).

Dede Korkut Kitabı'nın bilinen iki nüshası vardır. Bunlardan biri Dresden'de, diğeri ise Vatikan'da bulunmuştur. Dresden nüshası XIX. yüzyılın başında, Vatikan nüshası ise daha yakın bir dönemde bulunmuştur ve 1950'den beri bilinmektedir. Dede Korkut üzerindeki çalışmalar genel olarak Dresden nüshasına dayanmaktadır (Ergin, 1989: 56). 2019 yilında Dede Korkut ile ilgili yeni bir el yazması bulunmuştur (Ekici, 2019: 9-14).

Dede Korkut Hikâyeleri genel olarak birtakım mücadelelerin destanlarıdır. Bu mücadelelerden ikisi Oğuzların kendi aralarında geçer, bunlardan birinde mücadele bir beyin oğlu ile kendi adamları arasında (Boğaç Han), diğerinde İç Oğuz'la Dış Oğuz arasındadır (İç Oğuza Dış Oğuz Asi Olup Beyrek Öldüğü Boy); iki hikâyede mücadele doğa ve insanüstü kuvvetlere karşıdır (Deli Dumrul, Tepegöz); bunların dışında kalan sekiz hikâyede mücadele Oğuz beyleri ile kuzeydeki ve batıdaki düşmanlar arasındadır (Ergin, 1989: 26).

Dede Korkut Hikâyeleri'nde birçok ortak özellikler vardır. Bunların başlıcaları şöyle belirtilebilir: Her hikâyede Dede Korkut vardır. Dede Korkut her hikâyeye Oğuzname adını verir; genellikle hikâyelerin başlangıçları benzerdir; en yüksek mevkide Hanlar Hanı Bayındır Han ve sonrasında Salur Kazan vardır. Hikâyeler kurgu bakımından da ortak noktalara sahiptir; kahramanlar çok güçlüdür. Kahramanlar sıcak ve olumlu sunulur; kahramanlar gözü pek, iyi yürekli, soğukkanlı, asidir, çabuk öfkelenir; kahramanlar tam bir savaşçıdır, çok iyi ata biner ve kılıç kuşanırlar. Kahramanlar düşmanların tutsağı olur ve onu kurtarmaya bir yakını gider; hikâyelerdeki kişiler ya oldukça iyi ya da oldukça kötüdür; hikâyeler aynı temel çizgi üzerinde gelişir ve sonuçlanırlar; hikâyelerde savaşlar yapılır, kan akıtılır. Oğuz beyleri ve düşman beylerinin tanıtımında ortak kalıplar kullanılır; hikâyelerde aile kavramı öne çıkar, aile üyeleri birbirine oldukça bağlıdır; kadına önem verilir ve saygı gösterilir. Kadınlar kocalarına çok saygılıdır; hikâyelerde sık sık ava çıkılır. Hikâyelerin geçtiği coğrafya temelde aynıdır ancak bu coğrafyanın üzerinde yapay bir üst coğrafya oluşmuştu. Hikâyelerde çok güzel bir coğrafi tasvir yapılır, dağlar, ırmaklar, göller çok güzel bir dille tasvir edilir; hikâyelerde olayların anlatıldığı bölümler nesir, karşılıklı konuşmaların büyük bir bölümü ise nazımla aktarılır; hikâyelerde daha önce verilen bir bilgi tekrar gündeme getirilir. Metinler mutlu sonla biter, Dede Korkut 
gelir, gazi erenlerin başına ne geldiğini söyler, iyi dileklerde bulunur, dua eder (Üstünova, 2008: 138-144).

Dede Korkut'ta birçok kişi adı geçmektedir. Bu kişilerden biri Demir Gücü'dür. Bu çalışmamızda Dede Korkut'taki Demir Gücü'nü, adını, ailesini ve Dede Korkut'taki yerini inceleyeceğiz.

\section{Demir Gücü’nün Adı}

Dede Korkut Kitabi'nda Demür Gücü adı bir boyda, Salur Kazan'in Evi Yağmalandığı Boy'da geçer (Gökyay, 1973: 322; Ercilasun, 2004: 64). Bahaeddin Ögel'e göre, velilik sahibi olan Karaçuk Çoban'ın, kardeşlerinin adları Kıyan-gücü (Sel-gücü) ile Demir-gücü'dür ki, bunlar görkemli ve mitolojik adlardır (1995: 575). Hatice Çiğdem Gönen'e göre, Dede Korkut'ta, Karacuk Çoban'ın kardeşlerinin adı Demir Gücü ve Kıyan Gücü'dür, güç ise çoğunlukla iktidara gönderme yapan bir kavram olarak kullanılmaktadır. Karacuk Çoban'ın kardeşlerinin adları Kıyan Gücü, Demir Gücü fiziksel gücü işaret eden adlardır (2017: 34, 212).

Eski Türk Yazıtları'nda da kişi adı olarak geçen Temir kelimesi gerçek anlamda demir anlamına gelmektedir. Kişi adı olarak kulanıldığında ise, mecazî anlamda olarak, 'demir gibi sağlam' anlamında kullanılmıştır. Yenisey Yazıtları'ndaki kişi adlarında da görülen küç 'güç' kelimesi bu adları alan kişilerin güçlü olduklarını belirtmektedir (Useev, 2015: 29, 34).

Eski Türklerde Alp tipi insan söz konusu olduğundan, erkeklerin demir gibi sağlam olması gerektiğine inanılmış ve bu ad da erkeklere isim olarak verilmiştir. Eski Türklerde Demir adı sık kullanılmış önemli bir isimdir, tarihte çok sayıda kişinin adında görülür; Moğol İmparatorluğu'nun kurucusu Cengiz Han'ın bu unvanı almadan önce adı Temuçin'di ve Demirci demekti, ayrıca Timurlular Devleti'nin kurucusu Timur'un adı da Demir demekti. Gök-Türkler demirciydiler. Köroğlu Destanı'nda da Demircioğlu adlı kahraman vardır.

\section{Demir Gücü’nün Ailesi}

Dede Korkut'ta, Demir Gücü'nün, babası, anası, soyu ya da eşi veya çocuklarının olup olmadığı hakkında herhangi bir bilgi yoktur. Demir Gücü’nün sadece iki kardeşi hakkında bilgi vardır. Kazan'ın Kapulu Dervend'deki on bin koyununa bakan Karacuk Çoban'ın yanında Kıyan Gücü ve Demür Gücü adlı 


\section{ग(๑)}

kardeşleri vardır. $\mathrm{Bu}$ üç kardeşin de adları sadece Salur Kazan'ın Evi Yağmalandığı Boy'da geçmektedir. Bu destanda kardeşlerin yaşları belirtilmemiş olsa da, Kıyan Gücü ve Demür Gücü'nün Karacuk Çoban'ın kardeşleri olduğunun belirtilmesinden ve Karacuk Çoban'ın kardeşleri üzerindeki otoritesinden yola çıarak, kardeşlerin en büyügünün Karacuk Çoban olduğu düşünülebilir. Kardeşlerin adları söylenirken ilk Kıyan Gücü’nün adının söylenmesi, onun da Demir Gücü'nden daha büyük olduğunu gösterebilir. Buradan hareket edildiğinde, kardeşler arasında yaş bakımından büyüklük sırasının da destandaki adlarının sıralanışıyla uyumlu olduğu düşünülebilir: En büyük kardeş Karacuk Çoban, ortanca kardeş Kıyan Gücü, küçük kardeş Demir Gücü. Açıç̧a söylenmese de, Karacuk Çoban'ın yanında bulunan ve ona yardım eden bu iki kardeşinin de Karacuk Çoban gibi çobanlık yaptığı düşünülebilir. Kıyan Gücü ve Demir Gücü'nün ağabeylerinin yanında yer alarak, kendilerinden kaç kat fazla sayıdaki düşmanla kahramanca mücadele etmeleri, onların da Karacuk Çoban gibi, yiğit, mert Oğuz yiğitleri olduklarını göstermektedir. Salur Kazan'ın Evi Yağmalandığı Boy'da, Kazan'ın Kapulu Dervend'deki on bin koyununa bakan Karacuk Çoban'ın Kıyan Güci ve Demür Güci adlı iki kardeşi vardır (Tezcan \& Boeschoten, 2001: 5153). Karacuk Çoban'ın bir kardeşi, Dede Korkut Kitabinda Kıyan Gücü olarak geçmektedir. Dede Korkut Kitabı'nda adı bir boyda, Salur Kazan'in Evi Yağmalandı̆̆ı Boy'da geçer (Gökyay, 1973: 327; Ercilasun, 2004: 64). Kıyan Gücü, Salur Kazan'ın Evi Yağmalandığı Boy'un önemli kahramanlardan biri olan Karacuk Çoban'ın iki kardeşinden biridir. Kiyan Gücü, Karacuk Çoban'ın düşmanla yaptığı savaşta ölmüştür (Gökyay, 1973: CLXVII). Karacuk Çoban'ın diğer kardeşi, Dede Korkut Kitabı'nda Demür Gücü olarak geçmektedir. Dede Korkut Kitabı'nda adı bir boyda, Salur Kazan'in Evi Yağmalandığı Boy'da geçer (Gökyay, 1973: 322; Ercilasun, 2004: 64). Demür Gücü, Salur Kazan'in Evi Yağmalandı̆̆ı Boy'da, Karacuk Çoban'ın, kendisine baskın yapan kalabalık yağıya karşı yaptığı savaşta yanında bulunan ve şehit düşen iki kardeşinden biridir (Gökyay, 1973: CLVI).

\section{Dede Korkut'ta Demir Gücü}

Salur Kazan'in Evi Yağmalandığı Boy'da, avda olan Salur Kazan'ın evini, yurdunu yağmalayan, ailesini, yakınlarını tutsak alan düşmanlar, Kazan'a son bir darbe vurmak için onun Kapulu Dervend'deki on bin koyununu da ele geçirmek 


\section{ग(ब)}

istemişlerdir. Destanda bu sırada Karacuk Çoban'dan, gördüğü rüyadan, kardeşlerinden ve aldığı önlemlerden şöyle bahsedilmiştir:

“Gece yaturiken Karacuk Çoban kara kaygulu vaki'a gördi. Vaki'asindan sermürdi, örü turdı. Kıyan Güci, Demür Güci, bu iki kardaşı yanına aldl, ağılun kapusını berkitdi. Üç yerde depe gibi taş yıgdı. Ala kollı sapanını eline aldı" (Tezcan \& Boeschoten, 2001: 51-52).

Salur Kazan'in Evi Yağmalandığı Boy'da, Karacuk Çoban ve iki kardeşi, altı yüz atlı askerden oluşan düşman ordusu ile kahramanca savaşmıştır. Karacuk Çoban ile iki kardeşi üç yüz kişiyi yere sermişler, sonra Karacuk Çoban iki kardeşini kaybetmiş, sonunda düşman kaçmak zorunda kalmıştır:

"Erenler evreni Karaçuk Çoban sapanınun ayasına taş kodı, atdl. Birin atanda ikisin, üçin yıkdı. İkisini atanda üçin, dördin yıkdı. Kafirlerün gözine korhu düşdi. Karacuk Çoban kafirün üç yüzini sapan taşıylla yere bırakdı. İki kardaşı oha (sançıldı), düşdi, şehid oldı. Çobanun taşı dükendi. Koyun demez, keçi demez sapanınun ayasına kor atar, kâfiriylkar. Kafirün gözi korkdı, dünya âlem kafirün başına karanu oldl, eydür. "Yarımasun yarçımasun bu çoban bizüm hepümüz kırar olamı?" dediler dahı turmayub kaçdllar" (Tezcan \& Boeschoten, 2001: 53).

Orhan Şaik Gökyay'a göre, Kıyan Gücü, Salur Kazan'in Evi Yağmalandığı Boy'un önemli kahramanlardan biri olan Karacuk Çoban'ın iki kardeşinden biri olup, Karacuk Çoban'ın düşmanla yaptığı savaşta ölmüştür (1973: CLXVII). Faruk Sümer'e göre, Salur Kazan'ın Evi Yağmalandığı Boy'da, Kazan'ın, Karaçuk adlı çobanı, yani Karacuk Çoban, Şökli Melik'in baskınında beyinin sürüsünü düşmana karşı fedakârca korumuştu, kardeşleri Kaban Güci ve Demür Güci bu uğurda ölmüştü ve sonra da Karacuk Çoban, Kazan'ın Şökli Melik'e karşı savaşında yiğitlik göstererek, bunların armağanı olarak Kazan'ın imrahoru olmuştu (1959: 418). Bahaeddin Ögel'e göre, velilik sahibi olan Karaçuk Çoban'ın, kardeşlerinin adları Kıyan-gücü (Sel-gücü) ile Demir-gücü'dür ki, bunlar gerçekten görkemli ve mitolojik adlardır (1995: 575). F. Ferhan Parlak'a göre, Salur Kazan'in Evi Yağmalandığı Boy'da, Karaçık Çoban, hikâyeye katılan cefakeş insan tiplerinden en ünlüsü ve en büyüğüdür. Karaçık Çoban'ın gösterdiği cesaret ve Kazan'ın evini, hazinesini almak için yaptığı fedakârlık oldukça önemlidir. Çünkü o, bu yiğitliği ile halk servetini koruyup kollamıştır. Kazan'ın mahiyetindeki bütün bu mal-devlet, hazine, halkın servetidir, elin malıdır. Zaman zaman Kazan bunların tamamını halka paylaştırır (1999: 16). 


\section{ग(৫)}

Bu nedenle Karacuk Çoban ve kardeşleri Kıyan Gücü ve Demir Gücü, aslında sadece birer çoban olmayıp, Oğuz'un sınırı olan Derbent (Demirkapı)'de durmaları da dikkate alındığında, hanlarının, devletin, halkın malını ve sınırlarını koruyan Oğuz askerlerinden farksız olarak aslında çoban-er (çoban asker)'dirler. Bilindiği gibi o devirlerde herkes aynı zamanda gerektiğinde asker sayılıyordu. Karacuk Çoban ve kardeşleri Kıyan Gücü ve Demir Gücü, sadece Kazan'ın koyunlarını değil, aynı zamanda halkın malını ve ülkenin sınırlarını koruyorlardı ki, onların düşmanla kahramanca mücadelelerinin altında yatan önemli motivasyon kaynaklarından biri de bu kutsal görevi yapmanın verdiği ruh haliydi.

Ülkü Eliuz'a göre, Salur Kazan'ın Evi Yağmalandığı Boy'da, Karaçuk Çoban, beyi ve yurdu uğruna canını, canı kadar sevdiği kardeşlerini ve bütün varlığını feda etmeye hazır olup, Salur Kazan'ın çobanı olarak tanıtılan bu güçlü alp, cesaretin, gücün, yenilmezliğin, vefanın, bağlılı̆̆ın simgesidir. Karaçuk Çoban, yurdunu, beyinin emaneti olan hayvanları korumak için iki kardeşiyle birlikte büyük ve zahmetli bir mücadele vermişti ve bu mücadeleden iki kardeşinin kaybına rağmen başarıyla çıkmıştı. Onun önünde durulmaz gücü ve yenilmez bileği, kardeş acısıyla daha da çelikleşmişti. Düşmandan hem kendinin hem de Salur Kazan'ın intikamını almak zorunda olduğunu hissetmişti (2000: 142).

Ümral Kırman'a göre, Salur Kazan'in Evi Yağmalandığı Boy'da, Karacuk Çoban, düşmanın üç yüzünü sapan taşıyla yere sermiş, taşı tükenince de düşmanın üzerine koyun, keçi demeyip sürüsündeki tüm hayvanları fırlatmıştır. Karacuk Çoban'ın kardeşleri bu mücadelede ölmüşlerdi, o ise sadece bir sapanla kalabalık bir düşman topluluğuyla başa çıkmış, düşmanları kaçırmış, kardeşlerini gömmüş, yarasını doğanın dilini kullanarak, keçesini yakarak yaptı̆̆ı isle tedavi etmiştir. $\mathrm{Bu}$ güçlü adam, daha sonra oturup çaresiz çocuklar gibi ağlayıp sızlamıştır, duygularını bastıramamıştır. Çünkü o, ruhsal olarak kültürden daha çok doğaya ait olup, doğaya yakınlığı ona neredeyse insanüstü fiziksel bir güç sağlamıştır. Destanda Karacuk Çoban'ın yanında yer alan kişiler, ona kan bağıyla bağlı kardeşleri iken, karşı taraf, yani düşman ise belirli bir çıkar etrafında bir araya gelmiş bir topluluktur. Saldırı öncesi düşmanlar, sayıca az olan tarafı, Karacuk Çoban'ı kandırmaya çalışarak mal-mülk ve beylik vereceklerini söylemişlerdir ki, kalabalık tarafın üç kişiden oluşan karşı tarafla uzlaşma çabası içinde oluşu dikkat çekicidir. Ama Karacuk Çoban, her şeye rağmen düşmanlara karşı durmuş 
ve onlara kafa tutmuştur. Tek başına düşmanı yenen ve dağıtan, böylelikle Salur Kazan'ın onurunu koruyan Karacuk Çoban, Salur Kazan'ın ona “oğul” diye seslendiğine bakılırsa Salur Kazan'dan daha genç bir kişidir (2004: 17-18, 156). Buradan yola çıkarak, Karacuk Çoban'ın kardeşleri Kıyan Gücü ve Demir Gücü'nün de genç yaşta oldukları söylenebilir.

Mehmet Emin Bars'a göre, Salur Kazan'in Evi Yağmalandığı Boy'da, düşman üzerine gitmek için Karaçuk Çoban'ın gerekçesi Salur Kazan'a göre daha gerçekçidir. Çünkü Salur Kazan, düşmandan, malını, tutsak anasını, karısını ve oğlunu almak için gider, fakat çobanın kardeşleri öldürülmüştür. Onların kanını almak, ölen kişinin öcünü almak, sağ olanların intikamını almaktan daha önemlidir. Bu açıdan çobanın düşüncesi daha öncelikli görünmektedir (2010: 60$61)$.

Gülcan Uyumaz’a göre, Salur Kazan'ın Evi Yağmalandığı Boy'da, Karaçuk Çoban, beyinin emaneti olan koyun sürüsünü korumak için büyük bir kahramanlık göstermiş, kendini ve iki kardeşini tehlikeye atmış, iki kardeşi düşman karşısında şehit olmuştur. Ancak o, pes etmemiştir. Karaçuk Çoban, tam bir cesaret ve yenilmezlik örneğidir. Düşman, Karaçuk Çoban'a beylik teklif etse de, Karaçuk Çoban bu teklifi asla kabul etmemiş ve onlara cevabını vermiştir. Destanda Karaçuk Çoban, mücadelesini bitirmeden asla geri çekilmemiş, hatta avdan dönen Salur Kazan bile bir an ümitsizliğe kapılsa bile, o dimdik ve kendinden emin bir şekilde öç almaya Salur Kazan'la birlikte gitmek istediğini belirtmiştir. Oraya kardeşlerinin intikamını almak için gittiğini söyleyen Karaçuk Çoban, tüm yiğitler gibi ailesinin öcünü almadan rahat etmez. Karaçuk Çoban ve Salur Kazan, Oğuz Beylerinin de yardımıyla düşmanı yenmişlerdir, ikisi de tam bir yiğit gibi davranmışlardır ve toplumun kendisinden beklediklerini yerine getirmişlerdir (2012: 72-73).

Süleyman Teyek'e göre, Salur Kazan'ın Evi Yağmalandığı Boy'da, Karacık Çoban, Salur Kazan'ın Kapılı Derbent'teki on bin koyununu, iki kardeşi ile güden ve koruyan çobanıdır. Karacık Çoban da kardeşleri de kılıçlı zümresinden kişiler değildir. Fakat Şökli Melik, üç çobanın üzerine altı yüz atlı asker göndermiştir ki, bu askerlerin sayısı ve zümresi Oğuzların karşı karşıya olduğu tehlikeyi tayin etmek yanında, sivil üç çobanın üzerine o kadar askerin gönderilmesi, Şökli Melik'in korkaklığını, askeri beceriksizliğini ve zalimliğini vurgulamaya 
yöneliktir. Salur Kazan, Karacık Çoban'a nereye gittiğini sormuş, aslında onun niye arkasından geldiğini sorgulamıştır. Onun evi barkı gitmişse, Karacık Çoban'ın da iki kardeşinin alınacak intikamı vardı. Düşman aynı olsa da, o düşmanı ortadan kaldıracak iki farklı neden ortaya çıkmıştı. Aslında Karacık Çoban'ın iki kardeşi Salur Kazan'ın koyunlarını korumak uğruna öldüğü için onların intikamı alınacaksa bu husus da Salur Kazan'ın boynunun borcuydu. Ancak Karacık Çoban, kardeşlerinin intikamını ağası Salur Kazan'a ısmarlamayı ar sayardı, intikamını kendisi almak niyetindeydi. Karacık Çoban'ın, ölen iki kardeşi adına intikam gütmesi dikkate değerdir, kendisi üç yüz kişiyi öldürmüş, buna karşılık iki kardeşi ölmüştür. Eğer kısasa kısas mantığına göre bir intikam güdecekse, bunda kendisi zararlı çıkacaktır. Çünkü kardeşlerini kimin öldürdüğünü bilmesi mümkün görünmemekle birlikte, daha kaç kişiyi öldürerek intikam almış olacaktı. Bu bakımdan Karacık Çoban'ın, Salur Kazan'la birlikte gitmesinin birinci nedeni, ona yardım etmektir (2013: 359, 375-376).

Gürol Pehlivan'a göre, Salur Kazan'in Evi Yağmalandığı Boy'da, kâfirler, Kapılı Kara Derbend'de Kazan'ın koyun sürüsü olduğunu hatırlamış ve altı yüz kişilik bir ordu göndermişlerdir. Bu sırada bu sürüye bakan Karaçuk Çoban, kötü bir rüya görmüş, kardeşleri Kıyan Gücü ve Demir Gücü'nü yanına alarak hazırlık yapmaya başlamış, ağılın kapısını berkitmiş, yanına sapanıyla atabilmek için taş yığmıştır. Burada ilginç olan husus, çobanın gördüğü rüyanın gerçekliği üzerinde hiç şüpheye düşmeden hazırlıklara başlamasıdır (2015: 43). Burada dikkat çeken bir unsur da, kardeşleri Kıyan Gücü ve Demü Gücü'nün Karacuk Çoban'ın gördüğü rüyayı sorgulamayarak hemen birlikte hazırlık yapmaya başlamalarıdır. Anlaşıldığına göre, Kıyan Gücü ve Demir Gücü, Karacuk Çoban'ın manevi yönünün güçlü olduğunun farkındadır. Bu nedenle ona ve gördüğü rüyaya hemen inanmışlar, birlikte hazırlığa girişmişlerdir ki, bu da Karacuk Çoban'ın daha önceden yaşadığı bazı tecrübelerin bir sonucu olmalıdır.

Sadettin Özçelik'e göre, Dede Korkut'ta, develerden sorumlu sarvan, atlardan sorumlu $l k ı$ ı̧ı, koyunlardan sorumlu çoban vardı. Ayrıca çobanın, sahip olunan hayvan sayısına, ihtiyaca göre yardımcıları olurdu. Bütün çobanların başında imrahor bulunuyordu. Avcı kuşlardan sorumlu şahinci vb. kuşçular ve onların da yardımcıları vardı (2015: 527). Salur Kazan'ın Evi Yağmalandığı Boy'da, Kazan'ın Kapulu Dervend'deki on bin koyunun başında çobanlık yapan Karacuk Çoban'ın yanında bulunan kardeşleri Kıyan Gücü ve Demir Gücü’nün de Karacuk 


\section{Ј(৫)}

Çoban'ın yardımcıları olarak görev yaptıkları söylenebilir. İki kardeşin o gece tesadüfen orada bulunmaları düşük bir olasılıktır. On bin koyunluk büyük bir sürüye bakmak için, çobanın yanında yardımcıları ve birkaç tane de köpeği olması gerekir ki, ancak böyle bir ekip işiyle böyle büyük bir sürüye bakılabilir.

Mehmet Surur Çelepi'ye göre, Dede Korkut'ta, hikâyelerin çoğunda sadakat ve bağlllık görülmektedir. Salur Kazan'in Evi Yağmalandığı Boy'da, Karacuk Çoban'ın iki kardeşi, Salur Kazan'ın koyunlarını, malını korurken düşman tarafından öldürülmüştür (2016: 359). Bu bakımdan, Karacuk Çoban, Kıyan Gücü ve Demir Gücü kardeşler arasında örnek bir bağll1ık görülmektedir.

Hatice Çiğdem Gönen'e göre, Dede Korkut'taki en değişik karakterlerden birisi olan Karacuk Çoban'ın olağandışı olarak nitelendirilebilecek güçleri vardır ki, bir ağacı yerinden söküp koca bir orduyu sapanıyla dağıtabilmektedir. Karacuk Çoban'ın kardeşlerinin adı Demir Gücü ve Kıyan Gücü'dür, güç ise bilindiği gibi, çoğunlukla iktidara gönderme yapan bir kavram olarak kullanılmaktadır. Ancak destanda, Karacuk Çoban'ın kardeşleri savaşta ölmüşler, Karacuk Çoban tek başına bütün bir orduyu dağıtmıştır. Dede Korkut'ta adı yalnızca Salur Kazan'in Evi Yağmalandığı Boy'da geçen Karacuk Çoban, şaman motifleri görülen bir karakterdir. Bu destan barındırdı ̆̆ 1 Şamanik unsurlar bakımından da oldukça zengin bir içeriğe sahiptir. Karacuk Çoban'ın gösterdiği, ağacı yerinden sökmesi, tek başına koca bir ordu ile mücadele etmesi gibi olağanüstü motifler Karacuk Çoban'ın şamana benzer özellikler gösterdiği düşüncesini akla getirmektedir. Üstelik Karacuk Çoban'ın kardeşlerinin Kiyan Gücü, Demir Gücü gibi fiziksel gücü işaret eden adlara sahip olmasına rağmen, onlar ölmüş, fakat Karacuk Çoban düşmanı tek başına yenmiştir (2017: 34-35, 211-212).

Cemile Şen'e göre, Salur Kazan'in Evi Yağmalandığı Boy'da, Salur Kazan'ın Kapılı Kara Dervend'deki on bin koyununu ele geçirmek için yola çıkan altı yüz kişilik düşman karşısında, Karacık Çoban ve iki kardeşinin savaşması ve kardeşlerinin ölmesine rağmen bu savaştan Karacık Çoban'ın tek başına galip gelmesi, olağanın sınırlarını zorlayan bir mümkünlüğe dönüşmüştür (2018: 57).

Tuğba Akkoyun Koç’a göre, Karacuk Çoban, bir ağacı yerinden söküp götürebilecek kadar olağanüstü güçte biridir ki, başına gelecekler ona rüya yoluyla ilham edilir. Bu özellikler onu kutsallaştırmaktadır. O, sıradan bir insan 


\section{Ј(৫)}

değildir. Hem Kazan Han hem de kâfir, Çoban'a seslenirken "Karanku ahşam olanda kaygulu çoban, Karıla yağmur yağanda çakmaklu çoban" ifadelerini kullanmışlardır. Karşıt iki grubun da Çoban'a aynı şekilde hitap etmesi dikkat çekicidir. Çoban, genelgeçer özellikte bir kavramla ilişkilidir. Çakmak, Çoban'ın hikâye içindeki kavram alanı açısından önemlidir. Orta Asya ve Sibirya mitolojilerinde ateşin gökten geldiği görülmektedir, ilk ateşin Tanrı tarafından yıldırım aracıllğıyla verildiği düşünülmüştür. Yıldırım ve şimşek Türklerde olumlu karşılanan, kutsal görülen doğa olaylarıdır. Orta Asya'da ve Anadolu ağızlarında yıldırım anlamında kullanılan çakın sözcüğü de Türkçedeki çakmak fiiliyle ilgilidir. Demir/çelik, ateşte eritilerek işlenir, istenen şekle ulaşılınca da su aracılığıyla sertleştirilir. Yani demir, var olma döngüsündeki son şeklini su ile tamamlar. Türk mitik algısındaki demir, ateş ve su üçlüsü, Karacuk Çoban ve kardeşleri birleşiminde görülebilir. Çoban'ın bir kardeşinin adı Kıyan Güci (sel gücü), diğerinin adı Demür Güci'dir, Çoban da kutsal ateşi sağlayan yıldırımdır (2020: 57).

Tuğba Akkoyun Koç’a göre, çoban, yıldırım ilişkisinde dikkat çekici birçok bağ vardır; "Südi peniri bol, kaymaklu çoban" sözleri, Türklerin yıldırım için yaptıkları saçıları hatırlatmaktadır; Çoban, yıldırım olarak ele alındığında, kâfirler, Müslüman olmayan Türklerdir, çünkü yıldırıma karşı yaptıkları hareket aynıdır, yani ok atmaktır. Çoban'ın iki kardeşi de ok yoluyla öldürülmüştür. Ylldırıma açılan savaşta üç yüz kâfir ölmüş, yıldırımın demir ve sel gücü de kırılmıştır. Savaş bittiğinde Çoban, düşman leşinden büyük tepe yığıp, çakmak çakıp ateş yakmış, böylece yıldırım düşmüş ve kutsal ateş yanmıştır. Arındırıcı yönüyle ateş kötü ruhları temsilen kâfirleri yakmıştır, yok etmiştir. Yarasını saran Çoban yolun kıyısına oturup ağlamaya başladığında yıldırım bitmiş ve yağmur başlamıştır (2020: 57-58).

Aydoğan Kara'ya göre, Salur Kazan'in Evi Yağmalandığı Boy'da, hiyerarşik bakımdan düşük bir konumda olmakla birlikte, Oğuzların yaşamında çobanların da önemli bir yeri vardır. Karaçuk Çoban, Salur Kazan'ın hemen yanında, bir norm karakter olarak Kazan'ın yeniden erginlenmesinde büyük rol oynamıştır. Karaçuk Çoban'ın altı yüz kişiyle savaşarak ölen kardeşleri Kıyan Güçi ve Demür Güçi, işlevsel açıdan önemli olsalar da birer figüratif/fon karakterlerdir (2020: 46). 


\section{ग(๑)}

Salur Kazan'ın Evi Yağmalandığı Boy'da, birçok yerde Karacuk Çoban'ın çoban olduğu belirtilmesine karşın, kardeşleri Kıyan Gücü ve Demir Gücü’nün de bir çoban olduğu açıkça belirtilmemiştir. Kıyan Gücü ve Demir Gücü'nün Karacuk Çoban'ın yanında olmaları, Karacuk Çoban'a düşmana karşı hazırlanma konusunda yardım etmeleri, aslında onların da çoban olduğunu akla getirmektedir. Boyda çoban adiyla sadece Karacuk Çoban ön plana çıkarıldığından ve Salur Kazan ile birlikte Karacuk Çoban'ın fiilî olarak başkahraman konumunda bulunması nedeniyle, Kıyan Gücü ve Demir Gücü’nün çobanlığı geri plana atılmış, böylece çobanların ulusu olarak Karacuk Çoban idealleştirilmiştir. Bu idealleştirme, Dede Korkut'taki bey oğullarının beyin tek oğlu olması idealleştirmesi ile uyumludur. Bu bakımdan Kıyan Gücü ve Demir Gücü'nün de çoban oldukları, Karacuk Çoban'ın sahip olduğu birçok özelliğe sahip oldukları düşünülebilir.

Karacuk Çoban'ın olacakları önceden rüyasında görmesi ve rüyasında gördüklerinin gerçeğe dönüşmesi, onun sıradan bir insan olmayıp, manevi âlem ile olan bağının güçlü olduğunu, kâhinlik niteliklerinin bulunduğunu göstermektedir. Bu bakımdan Karacuk Çoban, eski Türklerin inanışı olan Şamanizm ile ilgilidir. Karacuk Çoban'ın kardeşleri, onun gördüğü rüyayı sorgulamadan ona yardım etmişlerdir ki, bu durum Karacuk Çoban'ın manevi yönünün gücünün kardeşleri tarafından da bilindiğini göstermektedir. Karacuk Çoban'ın bir kardeşinin adının Kıyan Gücü olması, bir kardeşinin de Demir Gücü olması, su ve demirin Şamanizm ile olan bağ düşünüldüğünde dikkat çekici bir ayrıntıdır. Burada olası bir ilişkiyi de dile getirmek isteriz: Karacuk Çoban'ın adı Oğuzların ünlü Karadağları/Karacuk ile, yani dă̆ ile ilgilidir. Karacuk Çoban'ın bir kardeşinin adı ise Demir Gücü'dür ki, demir ile ilgilidir. Dağ-demir ilişkisi destanın alt tabakasında bu kardeşleri eski Türklerin ünlü Ergenekon Destani'yla ilişkilendirebilir.

\section{Sonuç}

Dede Korkut'ta adı sadece Salur Kazan'in Evi Yağmalandığı Boy'da geçen Karacuk Çoban, destanda önemli bir yere sahip, güçlü, mert, yenilmez bir Oğuz yiğididir. Karacuk Çoban'ın kardeşleri Kıyan Gücü ve Demir Gücü'nün de, ağabeylerinin yanında yer alarak ona arka çıkmaları, kendilerinden iki yüz kat fazla sayıda düşman ordusuyla kahramanca mücadele etmeleri, onların da 
Karacuk Çoban gibi, yiğit, mert Oğuz yiğitleri oldukları görülmektedir. Karacuk Çoban ve kardeşleri Kıyan Gücü ve Demir Gücü arasında örnek bir kardeşlik ve bağlılık vardır. Bu o derecedir ki, Karacuk Çoban'ın kardeşleri Kıyan Gücü ve Demir Gücü, sonunda ölmek pahasına da olsa, altı yüz kişilik düşman topluluğuna karşı yiğitçe, mertçe, kahramanca ağabeylerinin yanında durmuşlardır, büyük bir kahramanlık göstermişlerdir ve bu yolda ölmüşlerdir. Cömert ve fedakâr insanlar, böyle kahramanlar tarihin her döneminde saygıyla anılmayı hak ederler. Kimi zaman bazı kardeşlerin taht mücadelesine girdiği bir dönemde bu kardeşlerin birbirlerine olan bağlılığı, aralarındaki kardeşlik bağı büyük değerdedir ve dün olduğu gibi, bugün ve yarın da gelecek kuşaklara kardeşliğin önemini ve değerini anlatacak, birlik ve beraberlik mesajı verecektir.

\section{Kaynakça}

Akkoyun Koç, T. (2020). Dede Korkut Hikâyelerinde Söylem Çözümlemesi ve Kültürel Kimliğin Öğretimi. Atatürk Üniversitesi, Eğitim Bilimleri Enstitüsü, Erzurum. (Yayımlanmamış Doktora Tezi)

Anar (2000). Kitabi-Dede Korkud Ensiklopediyast I. Bakı: Yeni Neşrler Evi.

Bars, M. E. (2010). Salur Kazan'ın Evi Yağmalandığı Boy'da Salur Kazan ve Çoban. The Journal of Academic Social Science Studies, 3(2), 55-63.

Bayat, F. (2016). Mitten Tarihe, Sözden Yazıya Dede Korkut Oğuznameleri. İstanbul: Ötüken Neşriyat.

Çelepi, M. S. (2016). Anadolu'daki Toplumsal Kimliğin İnşasında Dede Korkut Hikâyelerindeki Bireyin Tekâmülü. In Ekici, M. et al. (Eds.), III. Uluslararası Türk Dünyası Külttür Kongresi "Dede Korkut ve Türk Dünyası" (Çeşme-İzmir, 19-23 Ekim 2015) Bildiriler Kitabı I (pp. 341-362). İzmir: Ege Üniversitesi Yayınları.

Ekici, M. (2019). Dede Korkut Kitabı Türkistan/Türkmen Sahra Nüshast, Soylamalar ve 13. Boy, Salur Kazan'n Yedi Başlı Ejderhayı Öldürmesi, Orijinal Metin (Tıpkıbasım), Transkripsiyon, Aktarma. İstanbul: Ötüken Neşriyat.

Eliuz, Ü. (2000). Dede Korkut Hikâyelerinde Tipler. In Kahya-Birgül, A. \& ŞimşekCanpolat, A. (Eds.), Uluslararası Dede Korkut Bilgi Şöleni (Ankara, 19-21 Ekim 1999) Bildirileri (pp. 139-155). Ankara: Atatürk Kültür Merkezi Yayınları.

Ercilasun, A. B. (2004). Zikredilen Şahıslara Dayanılarak Dede Korkut Boylarının Kronolojik Sıralanması. Türk Dili Araştırmaları Ylllığı Belleten, 1998/I, 61-69. 
Ergin, M. (1989). Dede Korkut Kitabı I. Giriş-Metin-Faksimile. Ankara: Türk Tarih Kurumu Basım Evi.

Ergin, M. (2017). Dede Korkut Kitabı. İstanbul: Boğaziçi Yayınları.

Eyüboğlu, D. C. (2019). Korkut. İstanbul: Cinius Yayınları.

Gökyay, O. Ş. (1973). Dedem Korkudun Kitabı. İstanbul: Başbakanlık Kültür Müşteşarlığı Kültür Yayınları.

Gönen, H. Ç. (2017). Dede Korkut Hikâyeleri'nde Devlet Dışı Siyasallı. Ankara Üniversitesi Sosyal Bilimler Enstitüsü, Ankara. (Yayımlanmamış Master Tezi)

Kara, A. (2020). Salur Kazan'ın Mitik Macerasından Modern İnsanın Bilincine Arketipsel Sembolik Bir Çözümleme. Dede Korkut Uluslararası Türk Dili ve Edebiyatı Araştırmaları Dergisi, 9(22), 39-51.

Kırman, Ü. (2004). Dede Korkut Anlatılarının Karşıtlklar Kuramına Göre Çözümlemesi ve Bu Kuramın Anlatı Öğretiminde Kullanımı. Dokuz Eylül Üniversitesi Eğitim Bilimleri Enstitüsü, İzmir. (Yayımlanmamış Master Tezi)

Kocasavaş, Y. (2014). Korkut Ata'yla İlgili Bazı Kayıtların Düşündürdükleri. İlmi Araştırmalar, 8, 139-144.

Ögel, B. (1995). Türk Mitolojisi (Kaynakları ve Açıklamaları ile Destanlar) I-II. Ankara: Türk Tarih Kurumu Yayınları.

Özçelik, S. (2015). Dede Korkut Destanlarında Oğuzların Teşkilatlanması Hakkında Bazı Kültürel Unsurlar. In Gündüz, T. \& Cengiz, M. (Eds.), Hacettepe Üniversitesi Türkiyat Araştırmaları Enstitüsü, Oğuzlar/Dilleri, Tarihleri ve Kültürleri 5. Uluslararası Türkiyat Araştırmaları Sempozyumu (Ankara, 21-23 Mayıs 2014) Bildirileri (pp. 523-532). Ankara: Hacettepe Üniversitesi Türkiyat Araştırmaları Enstitüsü Yayınları.

Parlak, F. F. (1999). Dede Korkut Hikâyeleri'nin Türk Tarihindeki Yeri. Selçuk Üniversitesi Sosyal Bilimler Enstitüsü, Konya. (Yayımlanmamış Master Tezi)

Pehlivan, G. (2015). Dede Korkut Kitabında Yapı, İdeoloji ve Yaratım -Dresden ve Vatikan Nüshalarının Mukayeseli Bir incelemesi-. İstanbul: Ötüken Neşriyat.

Seydimbek, A. (2000). Korkut Ata Efsaneleri. In Nisanbayev, A. et al. (Eds.), Kazakistan'da Dede Korkut (pp. 49-95). Ankara: Atatürk Kültür Merkezi Yayınları.

Sümer, F. (1959). Oğuzlar'a Ait Destani Mahiyetde Eserler. Ankara Üniversitesi Dil ve Tarih-Coğrafya Fakültesi Dergisi, 17(3/4), 359-455.

Şen, C. (2018). Dede Korkut Anlatıları'nda Büyülü Gerçekçilik. Fırat Üniversitesi Sosyal Bilimler Enstitüsü, Elazı̆̆. (Yayımlanmamış Master Tezi) 


\section{J(ఠ)}

Teyek, S. (2013). Kitab-ı Dede Korkut'ta Diplomatik Lisan: Halkbilimi Bakımından Bir Anlam İncelemesi. Gazi Üniversitesi Sosyal Bilimler Enstitüsü, Ankara. (Yayımlanmamış Master Tezi)

Tezcan, S. \& Boeschoten, H. (2001). Dede Korkut Oğuznameleri. İstanbul: Yapı Kredi Yayınları.

Tural, S. (2006). Milli Destanlarımız Üzerine. In Bozdemir, S. (Ed.), Tarihten Destana Akan Duyarlllk (pp. 45-62). Ankara: Yüce Erek Yayınevi.

Useev, N. (2015). Yenisey Yazıtlarındaki Erkek Kişi Adlarında Geçen Kelimelere Göre Eski Türk Erkeği. Uluslararası Türkçe Edebiyat Kültür Eğitim Dergisi, 4(1), 25-38.

Uyumaz, G. (2012). Dede Korkut Hikâyelerinde Çocuk Eğitimi. Dokuz Eylül Üniversitesi Eğitim Bilimleri Enstitüsü, İzmir. (Yayımlanmamış Master Tezi)

Üstünova, K. (2008). Dede Korkut Kitabını Oluşturan Destanlardaki Ortak Özellikler. Turkish Studies, 3(1), 138-144. 